\title{
Association between Helicobacter pylori genotypes and severity of chronic gastritis, peptic ulcer disease and gastric mucosal interleukin-8 levels: Evidence from a study in the Middle East
}

\author{
lqbal Siddique ${ }^{1,2^{*}}$, Asmaa Al-Qabandi ${ }^{3}$, Jaber Al-Ali ${ }^{1}$, Waleed Alazmi ${ }^{1,2}$, Anjum Memon $^{4}$, Abu Salim Mustafa $^{5}$
} and Thamradeen $\mathrm{A}$ Junaid ${ }^{3}$

\begin{abstract}
Background: The varied clinical presentations of Helicobacter pylori (H. pylori) infection are most likely due to differences in the virulence of individual strains, which determines its ability to induce production of interleukin-8 $(\mathrm{IL}-8)$ in the gastric mucosa. The aim of this study was to examine association between cagA, vacA-s 1 and vacA-s2 genotypes of $H$. pylori and severity of chronic gastritis and presence of peptic ulcer disease (PUD), and to correlate these with IL-8 levels in the gastric mucosa.

Methods: Gastric mucosal biopsies were obtained from patients during esophagogastroduodenoscopy. The severity of chronic gastritis was documented using the updated Sydney system. H. pylori cagA and vacA genotypes were detected by PCR. The IL-8 levels in the gastric mucosa were measured by ELISA.

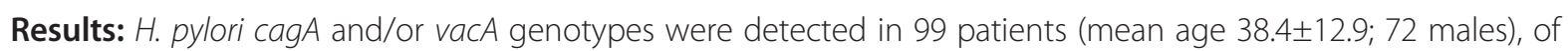
whom 52.5\% were positive for cagA, 44.4\% for vacA-s1 and 39.4\% for vacA-s2; and 70.7\% patients had PUD. The severity of inflammation in gastric mucosa was increased with vacA-s1 $(p=0.017)$ and decreased with vacA-s 2 $(p=0.025)$, while cagA had no association. The degree of neutrophil activity was not associated with either cagA or vacA-s1, while vacA-s2 was significantly associated with decreased neutrophil activity ( $p=0.027)$. PUD was significantly increased in patients with cagA $(p=0.002)$ and vacA-s1 $(p=0.031)$, and decreased in those with vacA-s2 $(p=0.011)$. The level of IL-8 was significantly increased in patients with cagA $(p=0.011)$ and vacA-s1 $(p=0.024)$, and lower with vacA-s2 $(p=0.004)$. Higher levels of IL-8 were also found in patients with a more severe chronic inflammation ( $p=0.001)$, neutrophil activity $(p=0.007)$ and those with PUD $(p=0.001)$.

Conclusions: Presence of vacA-s1 genotype of $H$. pylori is associated with more severe chronic inflammation and higher levels of IL-8 in the gastric mucosa, as well as higher frequency of PUD. Patients with vacA-s2 have less severe gastritis, lower levels of IL-8, and lower rates of PUD. The presence of cagA genotype is not associated with the severity of gastritis or IL-8 induction in the gastric mucosa. The association of cagA with PUD may be a reflection of its presence with vacA-s1 genotype.
\end{abstract}

Keywords: Helicobacter pylori, cagA, vacA-s1, vacA-s2, Gastritis, Interleukin-8, Peptic ulcer disease

\footnotetext{
* Correspondence: isiddique@hsc.edu.kw

'Department of Medicine, Faculty of Medicine, Kuwait University, P. O. Box 2492313110 Safat, Kuwait

${ }^{2}$ Thunayan Al-Ghanim Gastroenterology Center, Al-Amiri Hospital, Sharq, Kuwait

Full list of author information is available at the end of the article
}

\section{Biomed Central}

(c) 2014 Siddique et al.; licensee BioMed Central Ltd. This is an Open Access article distributed under the terms of the Creative Commons Attribution License (http://creativecommons.org/licenses/by/4.0), which permits unrestricted use, distribution, and reproduction in any medium, provided the original work is properly credited. The Creative Commons Public Domain Dedication waiver (http://creativecommons.org/publicdomain/zero/1.0/) applies to the data made available in this article, unless otherwise stated. 


\section{Background}

Helicobacter pylori (H. pylori) colonizes the mucosa of the human stomach and establishes a long-term infection [1]. It leads to the development of chronic gastritis, peptic ulcer disease (PUD), mucosal-associated lymphoid tissue (MALT) lymphoma and gastric carcinoma [2,3]. The extent and severity of these associations depend on several elements, such as bacterial virulence factors, age of the host, genetic susceptibility, immune response and environmental factors [4-6].

The two key virulence markers of H. pylori are the cytotoxin associated A ( $\operatorname{cagA})$ and the vacuolating cytotoxin A $(v a c A)$ genes [6,7]. The cagA gene is not present in every $H$. pylori strain, but is associated with more severe clinical results such as more severe inflammation of the gastric mucosa, as well as higher prevalence of PUD and gastric carcinoma [8-10]. The vacA gene is present in all H. pylori strains and is associated with PUD [11]. The $v a c A$ gene contains at least three variable regions, the signal (s) region, intermediate (i) region and middle (m) region. The s-region exists as s1 and s2 types $[12,13]$. The $v a c A-s 1$ strains are associated with more severe gastric inflammation and PUD independently of cagA, while $v a c A$-s2 strains are associated with lower ulcer prevalence and less severe inflammation [14].

H. pylori infection results in recruitment of neutrophils, lymphocytes and macrophages into the gastric mucosa through the induction of several cytokines such as TNF- $\alpha$, IL-6 and IL-8 [15-17]. IL-8 is an important mediator in the immunopathogenesis of chronic gastritis caused by $H$. pylori [16]. It has been demonstrated that cagA and $v a c A$-s1 positive strains of $H$. pylori induce production of IL-8 in the gastric mucosa, both in vivo and in vitro $[16,18,19]$. The $v a c A$-s2 gene is not associated with IL-8 induction [18]. In addition, an association between the mucosal levels of IL- 8 and severity of gastritis and presence of PUD has also been reported [19]. Most studies of association between genotypes of H. pylori and chronic gastritis, peptic ulcer disease and IL-8 levels have been conducted in the Western populations, and no previous study has examined these associations in the Middle East. Furthermore, the majority of published studies have only examined either a single or some of these associations.

The aim of this study was to determine the association between the presence of $c a g A, v a c A$-s1 and $v a c A$-s2 genotypes in $H$. pylori and the severity of gastritis and PUD, and to correlate these with the levels of IL- 8 in a group of patients from the Middle East. We have also attempted to examine all these inter-related associations in the same group of patients to validate the biologic plausibility that the bacterial virulence factors lead to induction of the cytokine IL-8, which in turn results in more severe inflammation or development of PUD.

\section{Results}

Esophagogastroduodenoscopy and gastric biopsies were performed in 120 adult patients. H. pylori were seen on histopathology in 98 of these patients, all of whom were positive for cagA and/or $v a c A$. One patient had $v a c A$ on PCR but was not positive for H. pylori on histopathology was also included in the analysis. Therefore, further analysis was carried out in these 99 patients $(72.7 \%$ males, $27.3 \%$ females; mean age 38.4 years) (Table 1 ). A history of PUD was present in $27.3 \%$ of the patients, and the most common indication for referral was dyspepsia (84.8\%).

The most frequent abnormality seen on endoscopy was PUD (70.7\%) (Table 2). Endoscopic evidence of mucosal inflammation of the stomach and duodenum was observed in $57.6 \%$ and $29.3 \%$ of the patients, respectively. Chronic inflammation was "None-Mild" in $22.2 \%$ of the patients, and "Moderate-Marked" in 77.8\%. Neutrophil activity was "None-Mild" in 60.6\%, and "Moderate-Marked" in $39.4 \%$ of the patients.

Table 1 Socio-demographic and clinical characteristics of 99 patients with $H$. pylori infection in Kuwait

\begin{tabular}{|c|c|c|}
\hline Characteristic & & \\
\hline \multicolumn{3}{|l|}{ Age at diagnosis (years) } \\
\hline Mean $\pm S D$ & \multicolumn{2}{|l|}{$38.4 \pm 12.9$} \\
\hline Median & \multicolumn{2}{|l|}{35.5} \\
\hline Range & \multicolumn{2}{|l|}{$18-75$} \\
\hline Gender & $\mathrm{n}$ & $(\%)$ \\
\hline Male & 72 & $(72.7)$ \\
\hline Female & 27 & $(27.3)$ \\
\hline \multicolumn{3}{|l|}{ Nationality } \\
\hline Kuwait & 52 & $(52.5)$ \\
\hline Bangladesh & 15 & $(15.2)$ \\
\hline Egypt & 8 & $(8.1)$ \\
\hline State-less Arabs & 5 & $(5.1)$ \\
\hline Syria & 5 & $(5.1)$ \\
\hline Other ${ }^{a}$ & 14 & $(14.1)$ \\
\hline Past history of peptic ulcer disease & 27 & $(27.3)$ \\
\hline Past history of $H$. pylori infection & 4 & $(4.0)$ \\
\hline History of cigarette smoking & 38 & $(38.4)$ \\
\hline History of alcohol consumption & 6 & $(6.1)$ \\
\hline \multicolumn{3}{|l|}{ Indication for esophagogastroduodenoscopy } \\
\hline Dyspepsia & 84 & $(84.8)$ \\
\hline Upper gastrointestinal bleeding & 6 & $(6.1)$ \\
\hline Heartburn & 5 & $(5.1)$ \\
\hline Anemia & 2 & $(2.0)$ \\
\hline Persistent vomiting & 2 & $(2.0)$ \\
\hline
\end{tabular}

India (4), Iran (2), Pakistan (2), Saudi Arabia (2), Afghanistan (1), Jordan (1), Somalia (1), Yemen (1). 
Table 2 Results of endoscopic, histological, H. pylori genotype, and IL-8 level in patients with $\boldsymbol{H}$. pylori infection in Kuwait

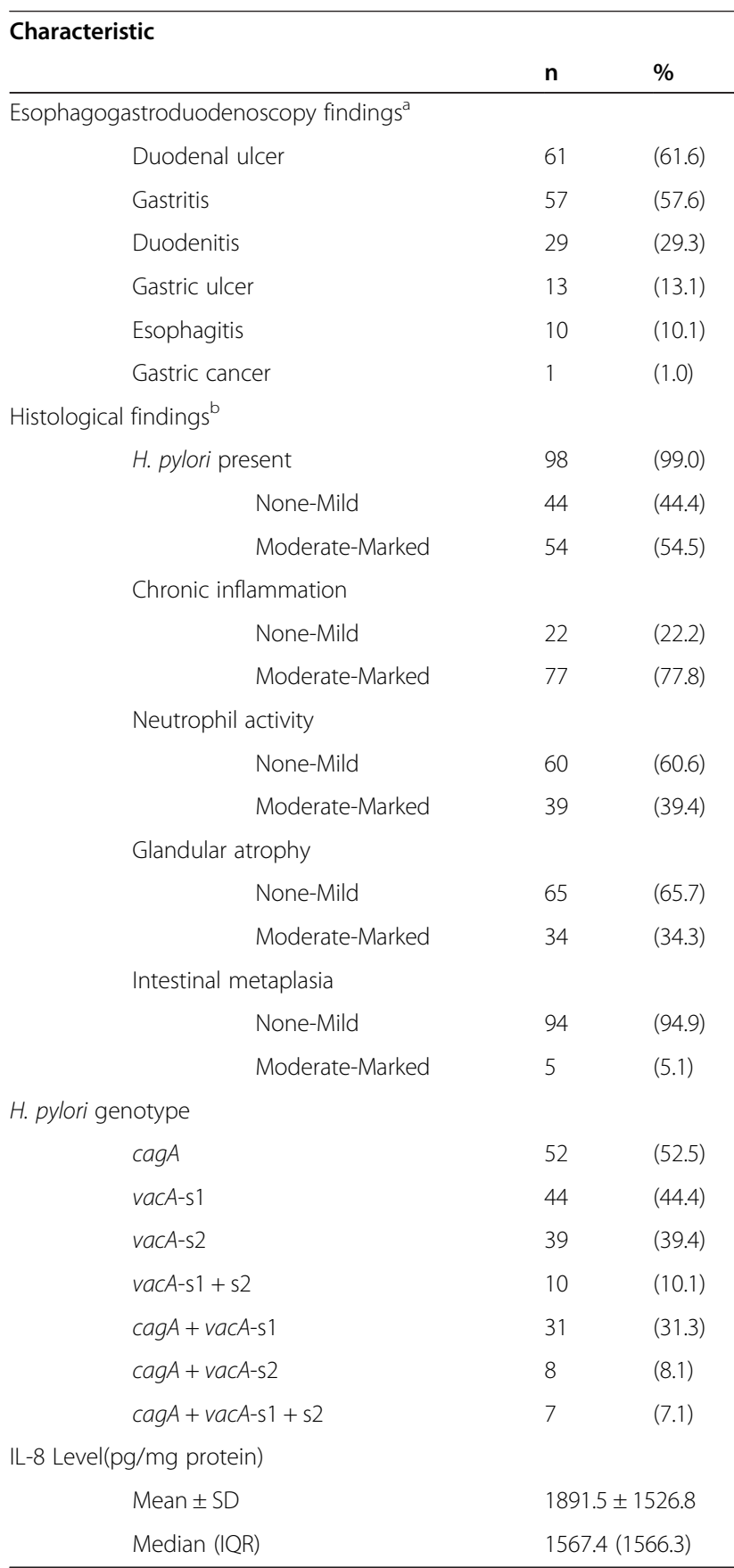

${ }^{a}$ Some patients had more than one finding on endoscopy.

${ }^{\mathrm{b}}$ According to the Updated Sydney system [40].

The presence of $\operatorname{cag} A, v a c A$-s 1 and $v a c A$-s 2 genes was found in $52.5 \%, 44.4 \%$ and $39.4 \%$ of the patients, while $10.1 \%$ were positive for both $v a c A$-s1 vacA-s2. The cagA gene was found in combination with vacA-s1 ( cagA + vacAs1) in $31.3 \%$ of the patients, with vacA-s2 (cagA + vacA-s2) in $8.1 \%$ and with both $v a c A$-s 1 and $v a c A$-s2 (cagA + vacA$\mathrm{s} 1+\mathrm{s} 2)$ in $7.1 \%$ of the patients. The IL-8 levels were available in 77 patients with a median value of 1567.4 (IQR 1566.3) $\mathrm{pg} / \mathrm{mg}$ protein.

Table 3 shows the association between the $H$. pylori genotypes and severity of chronic inflammation, neutrophil activity and presence of PUD. Patients who were infected with $H$. pylori containing both the cagA and $v a c A$-s1 genes were most likely to have "ModerateMarked" degree of chronic inflammation (OR $=6.7,95 \%$ CI: $1.4-31.4 ; \mathrm{p}=0.016$ ). Patients with vacA-s1 gene alone also had a significantly more "Moderate-Marked" degree of chronic inflammation (OR $=3.9,95 \%$ CI: 1.2$12.0 ; \mathrm{p}=0.017)$, while those with $v a c A-\mathrm{s} 2$ had significantly less chronic inflammation $(\mathrm{OR}=0.3,95 \% \mathrm{CI}$ : 0.1$0.8 ; \mathrm{p}=0.025)$. The presence of $\operatorname{cagA}$ or $v a c A$-s1 genes either independently or together did not affect the severity of neutrophil activity in the gastric biopsies. Patients with $v a c A$-s2 gene had a significantly less "Moderate-Marked" degree of neutrophil activity (OR = 0.3, 95\% CI: 0.1-0.8; $\mathrm{p}=0.027$ ). The proportion of patients having PUD was highest in those with the cagA gene $(\mathrm{OR}=4.8,95 \% \mathrm{CI}: 1.8-12.5 ; \mathrm{p}=0.002)$, followed by those with the vacA-s1 gene $(\mathrm{OR}=2.8,95 \% \mathrm{CI}$ : 1.1-7.4; $\mathrm{p}=0.031$ ), while those with $v a c A$-s2 had the lowest proportion of PUD (OR = 0.3, 95\% CI: 0.1-0.7; $\mathrm{p}=0.011$ ). The presence of both $\operatorname{cag} A$ and $v a c A$-s1 gene increased the risk of PUD more than the presence of these genotypes individually $(\mathrm{OR}=6.3,95 \% \mathrm{CI}$ : 1.6-23.4; $\mathrm{p}=0.006)$.

Table 4 shows the correlation between level of IL- 8 in the gastric mucosa and H. pylori genotypes and histologic features and PUD. The median value for IL- 8 was significantly higher in patients infected with $H$. pylori with $\operatorname{cag} A(\mathrm{p}=0.011)$ and $v a c A$-s1 genes $(\mathrm{p}=0.011$ and 0.024 , respectively); and significantly lower in those with $v a c A$-s2 gene $(\mathrm{p}=0.004)$ (Figure 1$)$. The highest levels of IL-8 were found in patients who were positive for both cagA and $v a c A$-s1 (Figure 2). Correlation of gastric mucosal IL-8 levels with the severity of chronic inflammation showed that patients who had "ModerateMarked" chronic inflammation had significantly higher median IL-8 level compared to those who had "NoneMild" inflammation ( $p=0.001$ ) (Figure 3). Patients with "Moderate-Marked" neutrophil activity on gastric biopsy also had significantly higher median IL-8 levels compared to those who had "None-Mild" activity ( $\mathrm{p}=$ 0.007). The median levels of IL- 8 were also significantly elevated in the gastric biopsies of patients with PUD compared to those who did not have ulcers ( $p=0.001$ ). There was no significant difference in the density of $H$. pylori or degree of glandular atrophy or intestinal metaplasia with the IL-8 level in the gastric biopsies.

A total of $58(75.3 \%)$ patients who had "ModerateMarked" chronic inflammation in the gastric mucosa had PUD, compared to 12 (54.5\%) with "None-Mild"; 
Table 3 Association between $H$. pylori genotypes and chronic inflammation, neutrophil activity and peptic ulcer disease

\begin{tabular}{|c|c|c|c|c|c|c|c|c|c|c|c|c|}
\hline \multirow{3}{*}{$\begin{array}{l}\text { H. pylori } \\
\text { genotype }^{\text {a }}(n)\end{array}$} & \multicolumn{4}{|c|}{ Chronic inflammation $^{b}$} & \multicolumn{4}{|c|}{ Neutrophil activity ${ }^{b}$} & \multicolumn{4}{|c|}{ Peptic Ulcer Disease } \\
\hline & $\begin{array}{l}\text { None-Mild } \\
\text { (n 22) }\end{array}$ & $\begin{array}{l}\text { Moderate-Marked } \\
\text { (n 77) }\end{array}$ & $\begin{array}{l}\text { OR } \\
(95 \% \mathrm{Cl})^{c}\end{array}$ & $p$-value & $\begin{array}{l}\text { None-Mild } \\
\text { (n 60) }\end{array}$ & $\begin{array}{l}\text { Moderate-Marked } \\
\text { (n 39) }\end{array}$ & $\begin{array}{l}\text { OR } \\
(95 \% \mathrm{Cl})^{\mathrm{c}}\end{array}$ & $p$-value & $\begin{array}{l}\text { Absent } \\
\text { (n 29) }\end{array}$ & $\begin{array}{l}\text { Present } \\
\text { (n 70) }\end{array}$ & $\begin{array}{l}\text { OR } \\
(95 \% \mathrm{Cl})^{\mathrm{c}}\end{array}$ & $p$-value \\
\hline & n (\%) & n (\%) & & & n (\%) & n (\%) & & & n (\%) & n (\%) & & \\
\hline \multicolumn{13}{|l|}{$\operatorname{cag} A$} \\
\hline Positive (52) & $8(15.4)$ & $44(84.6)$ & $2.4(0.9-6.7)$ & 0.074 & $29(55.8)$ & $23(44.2)$ & $1.5(0.6-3.4)$ & 0.325 & $8(15.4)$ & $44(84.6)$ & $4.8(1.8-12.5)$ & $0.002^{*}$ \\
\hline Negative (47) & $14(29.8)$ & $33(70.2)$ & Reference & & $31(66.0)$ & $16(34.0)$ & Reference & & $21(44.7)$ & $26(55.3)$ & Reference & \\
\hline \multicolumn{13}{|l|}{$\operatorname{vacA-s1}$} \\
\hline Positive (44) & $5(11.4)$ & $39(88.6)$ & $3.9(1.2-12.0)$ & $0.017^{*}$ & $22(50.0)$ & $22(50.0)$ & $2.2(0.9-5.2)$ & 0.057 & $8(18.2)$ & $36(81.8)$ & $2.8(1.1-7.4)$ & $0.031^{*}$ \\
\hline Negative (55) & $17(30.9)$ & $38(69.1)$ & Reference & & $38(69.1)$ & $17(30.9)$ & Reference & & $21(38.2)$ & $34(61.8)$ & Reference & \\
\hline \multicolumn{13}{|l|}{ vacA-s2 } \\
\hline Positive (39) & $13(33.3)$ & $26(66.7)$ & $0.3(0.1-0.8)$ & $0.025^{*}$ & $29(74.4)$ & $10(25.6)$ & $0.3(0.1-0.8)$ & $0.027^{*}$ & $17(43.6)$ & $22(56.4)$ & $0.3(0.1-0.7)$ & $0.011^{*}$ \\
\hline Negative (60) & $9(15.0)$ & $51(85.0)$ & Reference & & $31(51.7)$ & $29(48.3)$ & Reference & & $12(20.0)$ & $48(80.0)$ & Reference & \\
\hline \multicolumn{13}{|l|}{$\operatorname{vac} A-s 1+S 2$} \\
\hline Positive (10) & $3(30.0)$ & $7(70.0)$ & $0.5(0.1-2.2)$ & 0.445 & $8(80.0)$ & $2(20.0)$ & $0.3(0.0-1.7)$ & 0.191 & $2(20.0)$ & $8(80.0)$ & $1.8(0.3-9.1)$ & 0.478 \\
\hline Negative (89) & $19(21.3)$ & 70 (78.7) & Reference & & $52(58.4)$ & 37 (41.6) & Reference & & $27(30.3)$ & $62(69.7)$ & Reference & \\
\hline \multicolumn{13}{|l|}{$\operatorname{cag} A+\operatorname{vac} A-s 1$} \\
\hline Positive (31) & $2(6.5)$ & $29(93.5)$ & $6.7(1.4-31.4)$ & $0.016^{*}$ & $18(58.1)$ & $13(41.9)$ & $0.9(0.9-1.0)$ & 0.737 & $3(9.7)$ & $28(90.3)$ & $6.3(1.6-23.4)$ & $0.006^{*}$ \\
\hline Negative (68) & $20(20.9)$ & $48(70.6)$ & Reference & & $42(61.8)$ & $26(38.2)$ & Reference & & $26(38.2)$ & $42(61.8)$ & Reference & \\
\hline \multicolumn{13}{|l|}{$\operatorname{cag} A+v a c A-s 2$} \\
\hline Positive (8) & $3(37.5)$ & $5(62.5)$ & $0.4(0.1-2.2)$ & 0.337 & $5(62.5)$ & $3(37.5)$ & $0.9(0.2-4.3)$ & 0.959 & $2(25.0)$ & $6(75.0)$ & $1.2(0.2-6.5)$ & 0.810 \\
\hline Negative (91) & $19(20.9)$ & $72(79.1)$ & Reference & & $55(60.4)$ & 36 (39.6) & Reference & & $27(29.7)$ & $64(70.3)$ & Reference & \\
\hline \multicolumn{13}{|l|}{$\operatorname{cag} A+\operatorname{vac} A-s 1+s 2$} \\
\hline Positive (7) & $2(28.6)$ & $5(71.4)$ & $0.9(0.9-1.0)$ & 0.255 & $5(71.4)$ & $2(39.4)$ & $0.5(0.1-3.2)$ & 0.537 & $1(14.3)$ & $6(85.7)$ & $2.7(0.3-24.5)$ & 0.359 \\
\hline Negative (92) & $20(21.7)$ & $72(78.3)$ & Reference & & 55 (59.8) & $37(40.2)$ & Reference & & $28(30.4)$ & 64 (69.6) & Reference & \\
\hline
\end{tabular}

All patients were positive for either cagA, vacA or both

${ }^{\mathrm{b}}$ According to the Updated Sydney system [40].

${ }^{\mathrm{C}}$ Age and gender adjusted odds ratio.

*Statistically significant. 
Table 4 Correlation between interleukin-8 and $H$. pylori genotypes, chronic inflammation, neutrophil activity, and peptic ulcer disease

\begin{tabular}{|c|c|c|}
\hline H. pylori genotype ${ }^{a}$ & $\begin{array}{l}\text { Interleukin-8 level } \\
\text { Median (IQR) }\end{array}$ & $p$-value ${ }^{c}$ \\
\hline \multicolumn{3}{|l|}{$\operatorname{cag} A$} \\
\hline Absent & 1090.3 (1310.8) & $0.011^{*}$ \\
\hline Present & 1885.7 (1281.6) & \\
\hline \multicolumn{3}{|l|}{ vacA-s1 } \\
\hline Absent & $1245.8(1550.2)$ & $0.024^{*}$ \\
\hline Present & 1840.0 (1098.6) & \\
\hline \multicolumn{3}{|l|}{ vacA-s2 } \\
\hline Absent & $1840.0(1597.5)$ & $0.004^{*}$ \\
\hline Present & $965.6(1205.1)$ & \\
\hline \multicolumn{3}{|l|}{$\operatorname{vac} A-s 1+s 2$} \\
\hline Absent & $1541.1(1566.3)$ & 0.818 \\
\hline Present & $1711.8(1928.7)$ & \\
\hline \multicolumn{3}{|l|}{$\operatorname{cag} A+v a c A-s 1$} \\
\hline Absent & $1311.8(1814.9)$ & $0.021^{*}$ \\
\hline Present & 1901.7 (915.3) & \\
\hline \multicolumn{3}{|l|}{$\operatorname{cag} A+v a c A-s 2$} \\
\hline Absent & 1577.5 (1548.6) & 0.713 \\
\hline Present & $1331.7(-)$ & \\
\hline \multicolumn{3}{|l|}{$\operatorname{cag} A+\operatorname{vac} A s 1+s 2$} \\
\hline Absent & $1541.1(1625.9)$ & 0.807 \\
\hline Present & 1711.8 (1803.6) & \\
\hline \multicolumn{3}{|l|}{ Histological findings $^{d}$} \\
\hline \multicolumn{3}{|l|}{ Chronic inflammation } \\
\hline None-Mild & $689.2(1420.6)$ & $0.001^{*}$ \\
\hline Moderate-Marked & $1835.7(1345.3)$ & \\
\hline \multicolumn{3}{|l|}{ Neutrophil activity } \\
\hline None-Mild & $1449.0(1342.1)$ & $0.007^{*}$ \\
\hline Moderate-Marked & 1917.8 (2703.6) & \\
\hline \multicolumn{3}{|l|}{ Peptic ulcer } \\
\hline Absent & 919.3 (1153.3) & $0.001^{*}$ \\
\hline Present & $1890.6(1638.4)$ & \\
\hline
\end{tabular}

${ }^{a}$ All patients were positive for either cagA, vacA or both.

${ }^{\mathrm{b}} \mathrm{pg} / \mathrm{mg}$ protein.

'Mann-Whitney $U$ test.

${ }^{d}$ According to the Updated Sydney system [40].

*Statistically significant

while 31 (79.5\%) patients with "Moderate-Marked" neutrophil activity had PUD, compared to 39 (65.0\%) of those with "None-Mild" activity. However these differences were not statistically significant. There was also no association between the presence of PUD and severity of glandular atrophy, intestinal metaplasia or H. pylori density on gastric biopsies.

\section{Discussion}

To our knowledge, this is the first study to examine the association between the presence of cagA, vacA-s1 and $v a c A$-s2 genotypes in $H$. pylori and the severity of chronic gastritis and PUD in a group of patients from the Middle East. We have also demonstrated the relationship of these factors with the levels of IL-8 in the gastric mucosa validating the biologic plausibility that these bacterial virulence factors lead to induction of the cytokine IL-8, which in turn results in more severe inflammation and/or development of PUD.

There appears to be a geographic variation in the association between $H$. pylori genotypes and gastric inflammatory response. Infection with $\operatorname{cagA}$ positive strains of H. pylori in Western countries is reported to cause more severe gastric inflammation compared to Asian countries, where the results have been inconsistent [7,20-24]. In our study both the degree of chronic inflammation and neutrophil activity in the gastric mucosa were more severe in patients who were infected with $H$. pylori containing the $\operatorname{cag} A$ and $v a c A$-s1 genes. The presence of both $\operatorname{cag} A$ and $v a c A$-s 1 appeared to have a synergistic role in increasing the severity of inflammation in our patients. On the other hand, the presence of vacA-s2 appeared to improve the severity of chronic inflammation as well as neutrophil activity regardless of the presence of cagA, vacA-s1 or both. These findings are consistent with previously published studies where $v a c A$-s2 strains were found to be associated with less inflammation [25]. Both the $\operatorname{cagA}$ and $v a c A$-s1 genes were also independently associated with an increased risk of PUD, while the $v a c A$-s2 gene appeared to have a lesser effect. Patients who had both the $\operatorname{cag} A$ and the vacA-s1 gene had the highest risk of PUD. On the other hand, the presence of $v a c A$-s2 decreased the risk of PUD, whether it was present alone or with $\operatorname{cag} A, v a c A$-s1, or both. These results are similar to those reported from the Western countries $[20,21,24]$, even though the majority of the patients in our study were from the Middle East and the Indian Subcontinent [26]. A recent study conducted to determine the genetic affinities of $H$. pylori isolates from ethnic Arabs in Kuwait found that these strains are closely related to the Indo-European group of the organism and clearly distinct from the East Asian strains [27]. This could be the reason why the association of $\operatorname{cagA}$, $v a c A$-s 1 and $v a c A$-s 2 and gastritis and PUD in our patients seems to be similar to that reported from the Western countries.

The pro-inflammatory cytokine IL-8 plays an important role in the regulation of mucosal neutrophil migration and activation. Our results show that the level of IL-8 in the gastric mucosa was increased in presence of cagA and vacA-s1 genotypes of $H$. pylori and the highest levels were seen in patients who were positive for both 


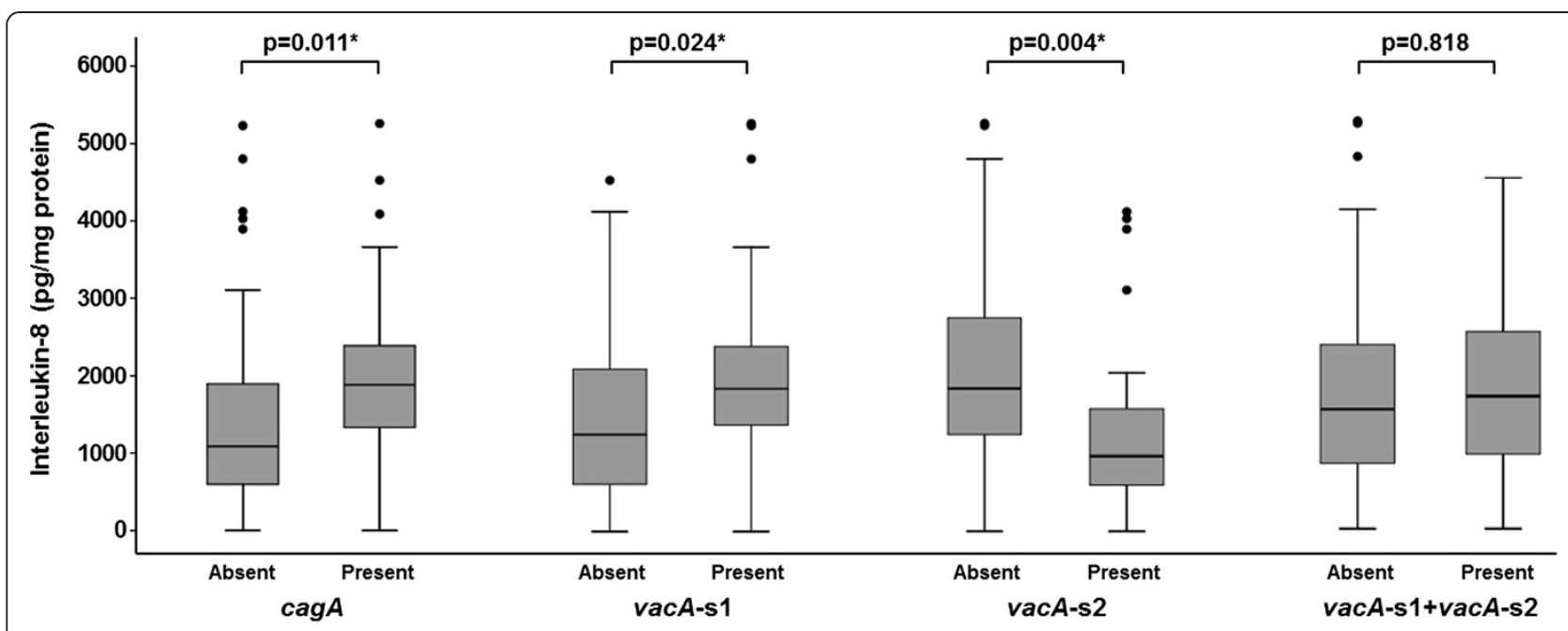

Figure 1 Levels of interleukin-8 in the gastric mucosa in patients with $H$. pylori with and without genotypes cagA, vacA-s1 and vacA-s2. These are expressed as box plots. The ends of the bars indicate the $25^{\text {th }}$ and $75^{\text {th }}$ percentiles. The $50^{\text {th }}$ percentile is indicated with a line, and the $10^{\text {th }}$ and $90^{\text {th }}$ percentiles are indicated with error bars. The $p$-values were calculated using the Mann-Whitney $U$ test. *indicates that the $p$-value is statistically significant.

these genes. The presence of vacA-s2 was associated with lower levels of IL-8. Significantly higher levels of IL-8 in the gastric mucosa were also seen in patients who had more severe degree of chronic inflammation and neutrophil activity in the gastric biopsies, as well as those who had PUD. These results are in agreement with previous reports where the levels of gastric mucosal IL-8 levels have been correlated with the presence of virulence $H$. pylori genes such as cagA and ice A $[28,29]$. However, some researchers have reported no difference in the IL-8 levels in patients with H. pylori infections with and without PUD [30], while others have higher levels in patients with PUD then those with only gastritis
[31]. This inconsistency in the results of IL-8 production could be because of the differences in the methodologies used to measure the level of the cytokine in the gastric mucosa. We have used an ELISA based technique, which may be a more sensitive method of cytokine quantification.

With reference to other factors, we found no difference in the severity of gastritis, presence of PUD or levels of IL8 between patients with or without history of smoking or alcohol consumption. The presence of PUD was however more frequent in this group of patients than has been reported previously from Kuwait as well as elsewhere [32]. The confounding effects of medications were minimized by only selecting those patients who had not been on any

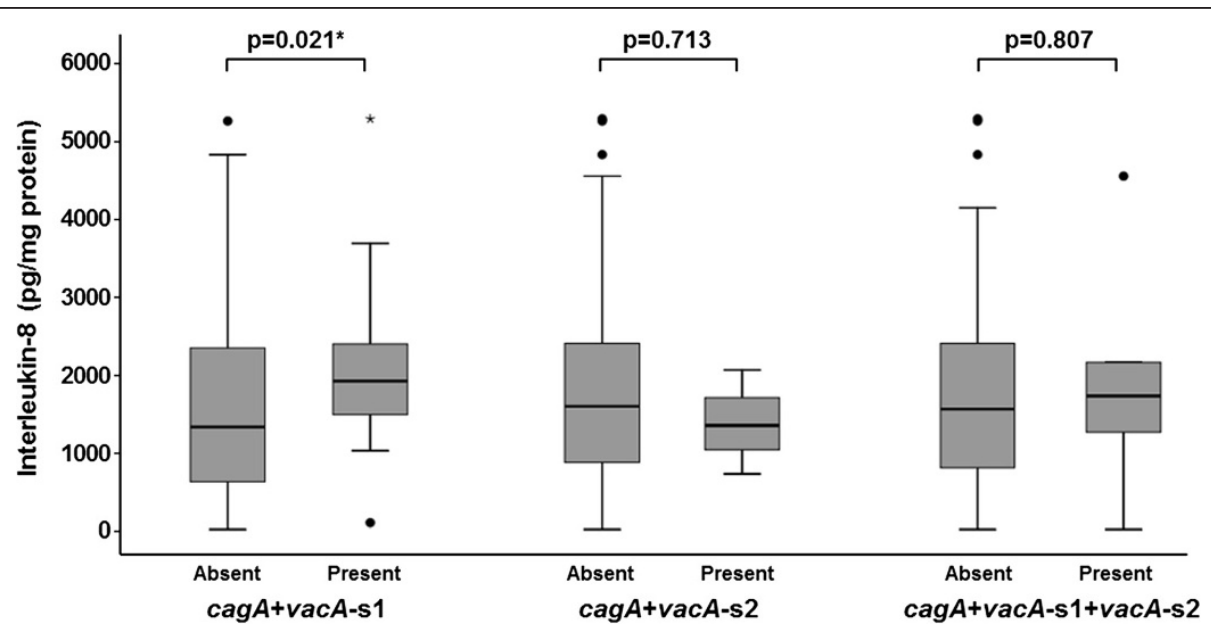

Figure 2 Levels of interleukin-8 in the gastric mucosa in patients with $H$. pylori with and without genotypes $\operatorname{cag} A+\operatorname{vac} A-s 1, \operatorname{cag} A+$ $v a c A-s 2$ and $c a g A+v a c A-s 1+v a c A-s 2$. These are expressed as box plots. The ends of the bars indicate the $25^{\text {th }}$ and $75^{\text {th }}$ percentiles. The $50^{\text {th }}$ percentile is indicated with a line, and the $10^{\text {th }}$ and $90^{\text {th }}$ percentiles are indicated with error bars. The $p$-values were calculated using the Mann-Whitney $U$ test. *indicates that the $p$-value is statistically significant. 


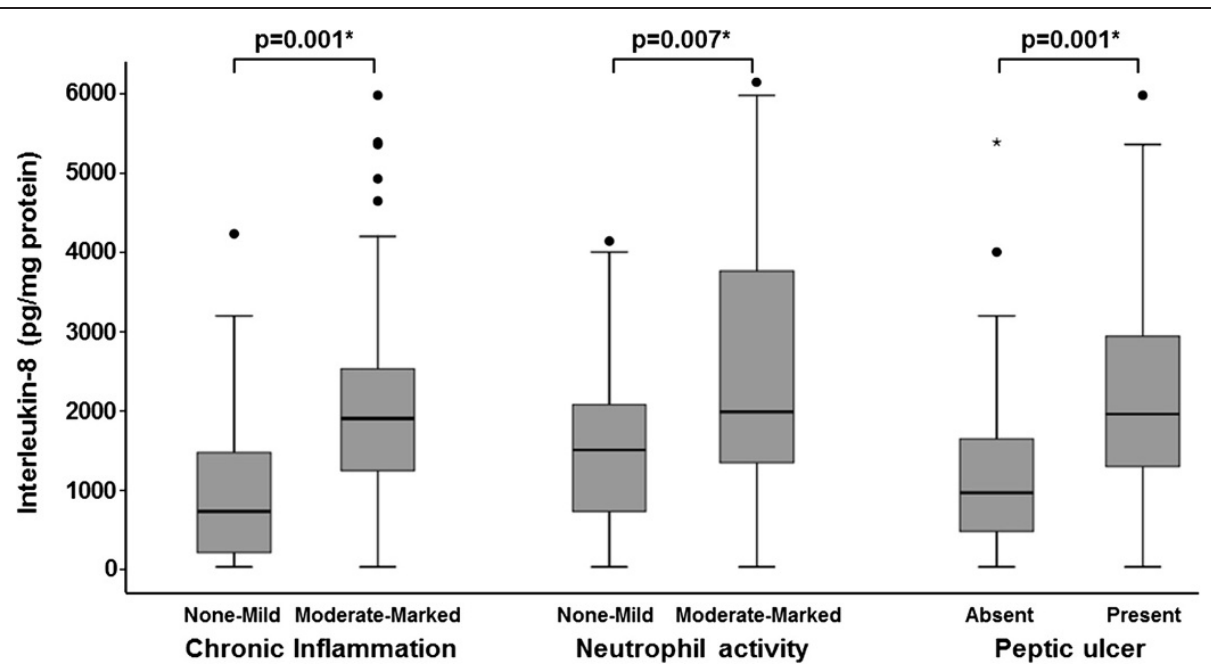

Figure 3 Levels of interleukin-8 in the gastric mucosa in patients with $H$. pylori and severity of chronic inflammation, neutrophil activity and peptic ulcer disease. These are expressed as box plots. The ends of the bars indicate the $25^{\text {th }}$ and $75^{\text {th }}$ percentiles. The $50^{\text {th }}$ percentile is indicated with a line, and the $10^{\text {th }}$ and $90^{\text {th }}$ percentiles are indicated with error bars. The p-values were calculated using the MannWhitney $U$ test. * indicates that the $p$-value is statistically significant.

of the mentioned medications for at least 4 weeks prior to endoscopy. Several other H. pylori factors such as $v a c A$-s1 subtypes (s1a and $\mathrm{s} 1 \mathrm{~b}), v a c A$ middle region subtypes ( $\mathrm{m} 1$ and $\mathrm{m} 2$ ), iceA and dupA genes can also affect the virulence of this organism and its effects on the gastric mucosa [33]. However, our study was not designed to determine these virulence factors, and this could be considered a limitation of this report. Besides bacterial factors, host genetics also contribute to the pathogenesis of gastroduodenal diseases [34,35]. In addition, many cytokine gene polymorphisms reveal different risk in gastric and duodenal ulcer patients [36,37].

\section{Conclusions}

This study which included patients from the Middle East shows that presence of $H$. pylori cagA and vacA-s1 genes results in induction of higher levels of the proinflammatory cytokine IL-8 in the gastric mucosa, which not only results in a more marked intensity of chronic inflammation and neutrophil activity in the gastric mucosa but also a higher occurrence of PUD. The presence of $v a c A$-s2 results in lower levels of IL-8, as well as less severe inflammation and less PUD. In addition the presence of $v a c A$-s2 appears to lessen the virulence effects of $\operatorname{cagA}$ and/or $v a c A$-s1 genes.

\section{Patients and methods}

\section{Patients and samples}

The study population and the method of biopsy collection have been described previously [26,32]. Briefly, 120 consecutive, unselected adult patients referred for esophagogastroduodenoscopy were invited to participate in the study. Patients with coagulation abnormalities, prior gastro-duodenal surgery were excluded from the study. Patients who had taken histamine type 2 receptor antagonists, proton pump inhibitors, antibiotics, bismuth salts, aspirin or non-steroidal anti-inflammatory agents in the preceding four weeks were also excluded. The prevalence of $\operatorname{cag} A$ and $v a c A$ genotypes in these patients has been reported earlier [26].

Upper gastrointestinal endoscopy was performed in a standard manner. All endoscopes underwent a cleaning and disinfection process with an automated washerdisinfector before each procedure according to guidelines of the European Society of Gastrointestinal Endoscopy [38]. For each patient, four biopsies were taken from the gastric antrum, within $2 \mathrm{~cm}$ of the pylorus, using sterilized biopsy forceps.

Two biopsy specimens were fixed in buffered formalin, processed to paraffin, sectioned and stained with H\&E and the HpSS [39]. All biopsies were examined individually by a senior gastrointestinal pathologist who was blinded to the clinical information about the patients. A biopsy was scored positive for H. pylori if organisms were seen on light microscopy. The updated Sydney system was used to score the density of $H$. pylori and degree of chronic inflammation, neutrophil activity, glandular atrophy and intestinal metaplasia on the biopsies [40]. Patients who had no or mild chronic inflammation in the gastric biopsy were combined in one group (None-Mild group), while those with moderate or marked degree of inflammation were included in the other group (Moderate-Marked group). Similarly, patients were divided into two groups (i.e. None-Mild and Moderate-Marked) for neutrophil activity, as well as for intestinal metaplasia and glandular atrophy. 
Table 5 Primers used in PCR for amplification of cagA, vacA-s1 and vacA-s2 sequences

\begin{tabular}{|c|c|c|c|}
\hline DNA region amplified & Primer & Primer sequence & PCR product $\left(b p^{a}\right)$ \\
\hline \multirow[t]{2}{*}{$\operatorname{cag} A$} & cagAF & 5'-TTGACCAACAACCACAAACCGAAG-3' & 183 \\
\hline & $\operatorname{cag} A R$ & 5'-CTTCCCTTAATTGCGAGATTCC-3' & \\
\hline \multirow[t]{2}{*}{$\operatorname{vac} A-s 1$} & VA1F & 5'-ATGGAAATACAACAAACACAC-3' & 176 \\
\hline & VA1XRA & 5'-CCTGAAACCGTTCCTACAGC-3' & \\
\hline \multirow[t]{2}{*}{ vacA-s2 } & VA1F & 5'-ATGGAAATACAACAAACACAC-3' & 203 \\
\hline & VA1XRA & 5'-CCTGAAACCGTTCCTACAGC-3' & \\
\hline
\end{tabular}

abp: Base pair.

The QIAamp ${ }^{\circ}$ DNA mini kit (Qiagen, Hilden, Germany) was used to extract DNA from the biopsies. The purity of DNA was assessed calculating the ratio of optical density (OD) at $260-280 \mathrm{~nm}$ and the yield was quantified by absorbance at $260 \mathrm{~nm}$.

\section{PCR amplification of target DNA}

Table 5 shows the primers used in this study. The cagAF and cagAR primers generate a fragment of 183 base pairs (bp) for the detection of $\operatorname{cag} A$, while primers VA1F and VA1XRA yield a $176 \mathrm{bp}$ fragment for $v a c A-s 1$ and 203 bp for $v a c A$-s2 variants [41,42]. A pre-aliquoted PCR master mix (Abgene, Surrey, UK) was used for PCR amplification of target DNA. The final reaction volume was $50 \mu \mathrm{L}$ and contained $25 \mathrm{pmol}$ of each primer and 50 ng DNA [43]. PCR was performed after preincubation at $94^{\circ} \mathrm{C}$ for 5 minutes, followed by 35 cycles at $94^{\circ} \mathrm{C}, 50^{\circ} \mathrm{C}$ and $74^{\circ} \mathrm{C}$ for one minute each followed by a 5 minutes final extension step at $74^{\circ} \mathrm{C}$. The amplified samples were analyzed by electrophoresis on $2 \%$ highresolution agarose gel in Tris-Acetate-EDTA (TAE) buffer, which was then stained with ethidium bromide at $0.5 \mu \mathrm{g} / \mathrm{ml}$ [44]. Ultraviolet light was used to visualize the bands of amplified DNA, which were then photographed.

\section{Measurement of IL-8}

Two biopsy specimens were frozen immediately in liquid nitrogen and stored at $-80^{\circ} \mathrm{C}$. These samples were later homogenized with $1 \mathrm{~mL}$ phosphate buffered saline $\left(\mathrm{pH}\right.$ 7.4) for 1 minute at $4^{\circ} \mathrm{C}$. The homogenate was then centrifuged for 10 minutes at $14,000 \mathrm{rpm}$. The supernatant obtained was used for estimation of IL-8 level as well as total protein measurement [45-47]. The IL-8 concentration was measured by IL-8 ELISA kit (Immunotech, Hamburg, Germany) in a sandwich type assay using the procedure recommended by the manufacturer. The modified Lowry method was used to measure the total protein in the homogenate [48]. The amount of IL-8 in the gastric mucosal biopsies was expressed as $\mathrm{pg} / \mathrm{mg}$ protein.

\section{Statistical analysis}

The Student's t-test was used to compare the difference between two means. We evaluated the association of PUD and severity of inflammation with the three H. pylori genotypes (cagA, vacA-s1 and vacA-s2) and their combinations. As our outcome measures were binary variables, we used univariate logistic regression models to test if any of the genotypes or their combinations are related to presence of the PUD or severity of inflammation. The strength of the association between these variables obtained from the regression models was expressed as the odds ratio (OR) and 95\% Confidence Interval (95\% CI) along with pvalues. Further multivariate logistic regression models were used to obtain age and gender adjusted estimates of these effects. We used Mann-Whitney U tests to evaluate if the levels of IL-8 correlated with varying genotypes or their combinations, severity of inflammation and presence of PUD. We used non-parametric method as the cytokines were not normally distributed. A p-value of $<0.05$ was considered statistically significant. All p-values presented are two sided. The data were analyzed using the SPSS software (SPSS Inc., Chicago, IL, USA).

The protocol for the study, and the statement of informed consent, was approved by the ethical committee of the Medical Research Council of the Health Sciences Center at Kuwait University and conforms to the provisions of the World Medical Association's Declaration of Helsinki in 1995 (as revised in Tokyo 2004). All patients gave an informed consent prior to inclusion in the study.

\section{Competing interests}

The authors declare that they hare no competing interests.

\section{Authors' contributions}

IS, AAQ, ASM and TAJ conceived and designed the study. IS, AAQ, ASM and TAJ collected the data. IS, AAQ, ASM and TAJ carried out experiments. IS, AAQ and AM statistically analyzed and interpreted the data. IS, AAQ, JAA and WA did literature research. IS generated the figures and tables. IS wrote the manuscript with help of AAQ, ASM, AM and TAJ. IS, AM. AAQ, ASM, TAJ, JAA and WA revised the paper. IS had full access to all of the data in the study and takes responsibility for the integrity of the data and accuracy of the data analysis. All authors had final approval of the submitted and published versions.

\section{Acknowledgements}

The authors thank Dr. Lukman Thalib for providing statistical advice.

\section{Disclaimer}

This work has been presented as a poster at the Digestive Disease Week (DDW $)$ 2012, in San Diego, California, USA in May 2012 and the abstract was published in Gastroenterology (2012;142:S-472-S-473). 


\section{Author details}

${ }^{1}$ Department of Medicine, Faculty of Medicine, Kuwait University, P. O. Box 2492313110 Safat, Kuwait. ${ }^{2}$ Thunayan Al-Ghanim Gastroenterology Center Al-Amiri Hospital, Sharq, Kuwait. ${ }^{3}$ Department of Pathology, Faculty of Medicine, Kuwait University, Jabriya, Kuwait. ${ }^{4}$ Division of Primary Care and Public Health, Brighton and Sussex Medical School, Brighton, UK.

${ }^{5}$ Department of Microbiology, Faculty of Medicine, Kuwait University, Jabriya, Kuwait.

Received: 16 July 2014 Accepted: 18 September 2014

Published online: 26 September 2014

\section{References}

1. Eusebi LH, Zagari RM, Bazzoli F: Epidemiology of Helicobacter pylori Infection. Helicobacter 2014, 19(Suppl 1):1-5.

2. Malnick SD, Melzer E, Attali M, Duek G, Yahav J: Helicobacter pylori: Friend or foe? World J Gastroenterol 2014, 20:8979-8985.

3. Marshall BJ, Windsor HM: The relation of Helicobacter pylori to gastric adenocarcinoma and lymphoma: pathophysiology, epidemiology, screening, clinical presentation, treatment, and prevention. Med Clin North Am 2005, 89:313-344.

4. O'Keeffe J, Moran AP: Conventional, regulatory, and unconventional T cells in the immunologic response to helicobacter pylori. Helicobacter 2008, 13:1-19.

5. Basso D, Plebani M, Kusters JG: Pathogenesis of Helicobacter pylori infection. Helicobacter 2010, 15(Suppl 1):14-20.

6. de Bernard $M$, Josenhans C: Pathogenesis of Helicobacter pylori Infection. Helicobacter 2014, 19(Suppl 1):11-18.

7. Umit H, Tezel A, Bukavaz S, Unsal G, Otkun M, Soylu AR, Tucer D, Otkun M, Bilgi S: The relationship between virulence factors of Helicobacter pylori and severity of gastritis in infected patients. Dig Dis Sci 2009, 54:103-110.

8. Almeida N, Donato MM, Romãozinho JM, Luxo C, Cardoso O, Cipriano MA Marinho C, Fernandes A, Sofia C: Correlation of helicobacter pylori genotypes with gastric histopathology in the central region of a southEuropean Country. Dig Dis Sci 2014, [Epub ahead of print].

9. Kim JY, Kim N, Nam RH, Suh JH, Chang H, Lee JW, Kim YS, Kim JM, Choi JW, Park JG, Lee YS, Lee DH, Jung HC: Association of polymorphisms in virulence factor of Helicobacter pylori and gastroduodenal diseases in South Korea. J Gastroenterol Hepatol 2014, 29:984-991.

10. Yamaoka Y, Graham DY: Helicobacter pylori virulence and cancer pathogenesis. Future Oncol 2014, 10:1487-1500.

11. Memon AA, Hussein NR, Miendje Deyi VY, Burette A, Atherton JC: Vacuolating cytotoxin genotypes are strong markers of gastric cancer and duodenal ulcer-associated Helicobacter pylori strains: a matched case-control study. J Clin Microbiol 2014, 52:2984-2989.

12. Atherton JC, Cao P, Peek RM Jr, Tummuru MK, Blaser MJ, Cover TL: Mosaicism in vacuolating cytotoxin alleles of Helicobacter pylori. Association of specific vacA types with cytotoxin production and peptic ulceration. J Biol Chem 1995, 270:17771-17777.

13. Rhead JL, Letley DP, Mohammadi M, Hussein N, Mohagheghi MA, Eshagh Hosseini M, Atherton JC: A new Helicobacter pylori vacuolating cytotoxin determinant, the intermediate region, is associated with gastric cancer. Gastroenterology 2007, 133:926-936.

14. Matos Jl, de Sousa HA, Marcos-Pinto R, Dinis-Ribeiro M: Helicobacter pylori CagA and VacA genotypes and gastric phenotype: a meta-analysis. Eur J Gastroenterol Hepatol 2013, 25:1431-1441.

15. Bodger K, Bromelow K, Wyatt Jl, Heatley RV: Interleukin 10 in Helicobacter pylori associated gastritis: immunohistochemical localisation and in vitro effects on cytokine secretion. J Clin Pathol 2001, 54:285-292.

16. Hisatsune J, Nakayama M, Isomoto H, Kurazono H, Mukaida N, Mukhopadhyay AK, Azuma T, Yamaoka Y, Sap J, Yamasaki E, Yahiro K, Moss J, Hirayama T: Molecular characterization of Helicobacter pylori VacA induction of IL-8 in U937 cells reveals a prominent role for p38MAPK in activating transcription factor-2, cAMP response element binding protein, and NF-kappaB activation. J Immuno/ 2008, 180:5017-5027.

17. Lee KE, Khoi PN, Xia Y, Park JS, Joo YE, Kim KK, Choi SY, Jung YD: Helicobacter pylori and interleukin-8 in gastric cancer. World J Gastroenterol 2013, 19:8192-8202.

18. Audibert C, Janvier B, Grignon B, Salaün L, Burucoa C, Lecron JC, Fauchère $\mathrm{J}$ : Correlation between IL-8 induction, cagA status and vacA genotypes in 153 French Helicobacter pylori isolates. Res Microbio/ 2000, 151:191-200.

19. Bartchewsky W Jr, Martini MR, Masiero M, Squassoni AC, Alvarez MC, Ladeira MS, Salvatore D, Trevisan M, Pedrazzoli J Jr, Ribeiro ML: Effect of Helicobacter pylori infection on IL-8, IL-1 beta and COX-2 expression in patients with chronic gastritis and gastric cancer. Scand J Gastroenterol 2009, 44:153-161.

20. Soltermann A, Koetzer S, Eigenmann F, Komminoth P: Correlation of Helicobacter pylori virulence genotypes vacA and cagA with histological parameters of gastritis and patient's age. Mod Pathol 2007, 20:878-883.

21. Gunn MC, Stephens JC, Stewart JA, Rathbone BJ, West KP: The significance of cagA and vacA subtypes of Helicobacter pylori in the pathogenesis of inflammation and peptic ulceration. J Clin Pathol 1998, 51:761-764.

22. Demirtürk L, Ozel AM, Yazgan Y, Solmazgül E, Yildirim S, Gültepe M, Gürbüz AK: CagA status in dyspeptic patients with and without peptic ulcer disease in Turkey: association with histopathologic findings. Helicobacter 2001, 6:163-168.

23. Saruç M, Demir MA, Küçükmetin N, Kandiloglu AR, Akarca US, Yüceyar H: Histological and clinical predictive value of determination of tissue CagA status by PCR in Helicobacter pylori infected patients; results of the large population based study in western Turkey. Hepatogastroenterology 2002, 49:878-881.

24. Warburton VJ, Everett S, Mapstone NP, Axon AT, Hawkey P, Dixon MF: Clinical and histological associations of cagA and vacA genotypes in Helicobacter pylori gastritis. J Clin Pathol 1998, 51:55-61.

25. Atherton JC, Peek RM Jr, Tham KT, Cover TL, Blaser MJ: Clinical and pathological importance of heterogeneity in vacA, the vacuolating cytotoxin gene of Helicobacter pylori. Gastroenterology 1997, 112:92-99.

26. Al Qabandi A, Mustafa AS, Siddique I, Khajah AK, Madda JP, Junaid TA: Distribution of vacA and cagA genotypes of Helicobacter pylori in Kuwait. Acta Trop 2005, 93:283-288.

27. Albert MJ, Al-Akbal HM, Dhar R, De R, Mukhopadhyay AK: Genetic affinities of Helicobacter pylori isolates from ethnic Arabs in Kuwait. Gut Pathog 2010, 2:6.

28. Ma YJ, Duan GC, Zhang RG, Fan QT, Zhang WD: Mutation of iceA in Helicobacter pylori compromised IL-8 induction from human gastric epithelial cells. J Basic Microbiol 2010, 50(Suppl 1):S83-S88.

29. Naito M, Eguchi H, Goto Y, Kondo T, Nishio K, Ishida Y, Kawai S, Okada R, Hishida A, Wakai K, Hamajima N: Associations of plasma IL-8 levels with Helicobacter pylori seropositivity, gastric atrophy, and IL-8 T-251A genotypes. Epidemiol Infect 2010, 138:512-518.

30. Noach LA, Bosma NB, Jansen J, Hoek FJ, van Deventer SJ, Tytgat GN: Mucosal tumor necrosis factor-alpha, interleukin-1 beta, and interleukin8 production in patients with Helicobacter pylori infection. Scand J Gastroenterol 1994, 29:425-429.

31. Peek RM Jr, Miller GG, Tham KT, Perez-Perez Gl, Zhao X, Atherton JC, Blaser $\mathrm{MJ}$ : Heightened inflammatory response and cytokine expression in vivo to cagA + Helicobacter pylori strains. Lab Invest 1995, 73:760-770.

32. Siddique I, Al-Mekhaizeem K, Alateeqi N, Memon A, Hasan F: Diagnosis of Helicobacter pylori: improving the sensitivity of CLOtest by increasing the number of gastric antral biopsies. J Clin Gastroenterol 2008, 42:356-360.

33. Alam J, Maiti S, Ghosh P, De R, Chowdhury A, Das S, Macaden R, Devarbhavi $H$, Ramamurthy T, Mukhopadhyay AK: Significant association of the dupA gene of Helicobacter pylori with duodenal ulcer development in a South-east Indian population. J Med Microbiol 2012, 61:1295-1302.

34. Höcker $M$, Hohenberger P: Helicobacter pylori virulence factors-one part of a big picture. Lancet 2003, 362:1231-1233.

35. Varon C, Mosnier JF, Lehours P, Matysiak-Budnik T, Mégraud F: Gastric carcinogenesis and Helicobacter pylori infection. Methods Mol Biol 2009, 511:237-265.

36. Wex T, Bornschein J, Malfertheiner P: Host polymorphisms of immune regulatory genes as risk factors for gastric cancer. Minerva Gastroenterol Dietol 2009, 55:395-408.

37. Lanas A, García-González MA, Santolaria S, Crusius JB, Serrano MT, Benito R, Peña AS: TNF and LTA gene polymorphisms reveal different risk in gastric and duodenal ulcer patients. Genes Immun 2001, 2:415-421.

38. The European Society of Gastrointestinal Endoscopy: Guidelines on cleaning and disinfection in Gl endoscopy. Update 1999. Endoscopy 2000, $32: 77-80$.

39. Doglioni C, Turrin M, Macrì E, Chiarelli C, Germanà B, Barbareschi M: HpSS: a new silver staining method for Helicobacter pylori. J Clin Pathol 1997, 50:461-464. 
40. Dixon MF, Genta RM, Yardley JH, Correa P: Classification and grading of gastritis. The updated Sydney System. International Workshop on the Histopathology of Gastritis, Houston 1994. Am J Surg Pathol 1996, 20:1161-1181.

41. van Doorn L, Figueiredo C, Sanna R, Plaisier A, Schneeberger P, de Boer W, Quint W: Clinical relevance of the cagA, vacA, and iceA status of Helicobacter pylori. Gastroenterology 1998, 115:58-66.

42. van Doorn LJ, Figueiredo C, Rossau R, Jannes G, van Asbroek M, Sousa JC, Carneiro F, Quint WG: Typing of Helicobacter pylori vacA gene and detection of cagA gene by PCR and reverse hybridization. J Clin Microbiol 1998, 36:1271-1276.

43. De Gusmão VR, Nogueira Mendes E, De Magalhães Queiroz DM, Aguiar Rocha G, Camargos Rocha AM, Ramadan Ashour AA, Teles Carvalho AS: vacA genotypes in Helicobacter pylori strains isolated from children with and without duodenal ulcer in Brazil. J Clin Microbiol 2000, 38:2853-2857.

44. Mustafa AS, Ahmed A, Abal AT, Chugh TD: Establishment and evaluation of a multiplex polymerase chain reaction for detection of mycobacteria and specific identification of Mycobacterium tuberculosis complex. Tuber Lung Dis 1995, 76:336-343.

45. Yamaoka Y, Kita M, Kodama T, Sawai N, Kashima K, Imanishi J: Induction of various cytokines and development of severe mucosal inflammation by cagA gene positive Helicobacter pylori strains. Gut 1997, 41:442-451.

46. Zhang QB, Etolhi G, Dawodu JB, Husain A, Gemmell CG, Russell RI: Relationship between mucosal levels of interleukin 8 and toxinogenicity of Helicobacter pylori. Inflammopharmacology 1998, 6:109-117.

47. Yamamoto S, Kaneko H, Konagaya T, Mori S, Kotera H, Hayakawa T, Yamaguchi C, Uruma M, Kusugami K, Mitsuma T: Interactions among gastric somatostatin, interleukin-8 and mucosal inflammation in Helicobacter pylori-positive peptic ulcer patients. Helicobacter 2001, 6:136-145.

48. Noble JE, Bailey MJ: Quantitation of protein. Methods Enzymol 2009, 463:73-95.

doi:10.1186/s13099-014-0041-1

Cite this article as: Siddique et al:: Association between Helicobacter pylori genotypes and severity of chronic gastritis, peptic ulcer disease and gastric mucosal interleukin-8 levels: Evidence from a study in the Middle East. Gut Pathogens 2014 6:41.

\section{Submit your next manuscript to BioMed Central and take full advantage of:}

- Convenient online submission

- Thorough peer review

- No space constraints or color figure charges

- Immediate publication on acceptance

- Inclusion in PubMed, CAS, Scopus and Google Scholar

- Research which is freely available for redistribution 